\title{
The Synergic Effect of Whey-Based Hydrogel Amendment on Soil Water Holding Capacity and Availability of Nutrients for More Efficient Valorization of Dairy By-Products
}

\author{
Jarmila Čechmánková ${ }^{1, *}$, Jan Skála ${ }^{1}$, Vladimír Sedlařík ${ }^{2}$, Silvie Duřpeková ${ }^{2}$, Jan Drbohlav ${ }^{3}$, \\ Alexandra Šalaková ${ }^{3}$ and Radim Vácha ${ }^{1}$ \\ 1 Department of Soil Hygiene, Research Institute for Soil and Water Conservation, Zabovreska 250, Zbraslav, \\ 15627 Prague, Czech Republic; skala.jan@vumop.cz (J.S.); vacha.radim@vumop.cz (R.V.) \\ 2 Centre of Polymer Systems, University Institute, Tomas Bata University in Zlin, Tr. T. Bati 5678, \\ 76001 Zlin, Czech Republic; sedlarik@utb.cz (V.S.); durpekova@utb.cz (S.D.) \\ 3 Dairy Research Institute, Ke Dvoru 12a, 16000 Prague, Czech Republic; drbohlav@milcom-as.cz (J.D.); \\ salakova@milcom-as.cz (A.Š.) \\ * Correspondence: cechmankova.jarmila@vumop.cz; Tel.: +420-606737098
}

Citation: Čechmánková, J.; Skála, J.; Sedlařík, V.; Duřpeková, S.; Drbohlav, J.; Šalaková, A.; Vácha, R. The Synergic Effect of Whey-Based Hydrogel Amendment on Soil Water Holding Capacity and Availability of Nutrients for More Efficient Valorization of Dairy By-Products. Sustainability 2021, 13, 10701. https:// doi.org/10.3390/su131910701

Academic Editors: Bharat Sharma Acharya and Rajan Ghimire

Received: 25 August 2021

Accepted: 19 September 2021

Published: 26 September 2021

Publisher's Note: MDPI stays neutral with regard to jurisdictional claims in published maps and institutional affiliations.

Copyright: (c) 2021 by the authors. Licensee MDPI, Basel, Switzerland. This article is an open access article distributed under the terms and conditions of the Creative Commons Attribution (CC BY) license (https:// creativecommons.org/licenses/by/ $4.0 /)$.

\begin{abstract}
Agricultural production is influenced by the water content in the soil and the availability of nutrients. Recently, changes in the quantity and seasonal water availability are expected to impact agriculture due to climate change. This study aimed to test an agricultural product with promising properties to improve soil quality and water-holding capacity during agricultural application. Most of the traditional hydrogels are low-biodegradable synthetic materials with under-researched long-term fate in field soil conditions. The novel, biodegradable hydrogel made from acid whey and cellulose derivatives cross-linked with citric acid was used. The soil-improving effects were tested under controlled experimental conditions with the sandy artificial soil consisting of $10 \%$ finely ground sphagnum peat, $20 \%$ kaolinite clay, and $70 \%$ quartz sand. Soil $\mathrm{pH}$, the content of organic carbon (Cox), total nitrogen $(\mathrm{N})$, available forms of the essential macronutrients $(\mathrm{P}, \mathrm{K}, \mathrm{Ca}$, and $\mathrm{Mg}$ ), the cation exchange capacity (CEC), the maximum water capacity (MWC) and water holding capacity (WHC) were determined. The results showed a positive effect on water retention and basic soil properties after the different levels of hydrogel had been introduced into the soil. Generally, the addition of whey-based hydrogel increases the available nutrients concentration and water retention in soil.
\end{abstract}

Keywords: hydrogel; soil quality; chemico-physical properties; sustainability

\section{Introduction}

The concept of agricultural sustainability spans both a way of thinking as well as of farming practices towards an environmentally sound, productive, economical, and socially needed agriculture [1]. The use of absorbent hydrogels in the field of agriculture presents several benefits for soil-conservation of water, reducing the usage of soil nutrients, and lowering the negative effects of dehydration and moisture stress in crop plants [2].

Hydrogels are a special part of gels, obtained by the chemical stabilization of hydrophilic polymers in a tridimensional network [3], having a remarkable ability to absorb water $[4,5]$. They show desirable physical and mechanical properties, and also economical reasonability in some cases. Polymer technology has provided a massive contribution to the development of novel cross-linking methods to design hydrogels. Various hydrogel preparation methods have been published for the formation of materials with various compositions, structures, and properties [6]. Due to their properties, they have been widely used in various fields ranging from industry and tissue engineering to pharmacy, medicine, cosmetics, and grocery [7]. Hydrogels are also widely utilized in forestry [8], reclamation [9], and agriculture where their good water retention and slow-release capacity 
showed promising results for the improvement of soil properties, reduction of fertilizer loss [10,11], or ameliorative advance fertilization [3].

An ideal hydrogel/superabsorbent for agricultural or industrial use must meet several requirements, including high capacity for absorption water and absorption rate, reasonable economy, stability after swelling and during storage, rewetting capability, and nontoxicity [12]. Most of the traditional hydrogels on the market are acrylate-based products, thus low-biodegradable materials with complicated fate in soils [13]. Whilst industrial utilization may profit from the high stability of (semi)-synthetic hydrogels with an effect of long service life, the same property may turn undesirable for environmentally friendly use in agriculture. With regard to the growing attention to environmental issues, biodegradable hydrogels are of particular interest for potential commercial use in agriculture [14]. Hydrogels derived from natural sources offer advantages over synthetic forms, owing to their biocompatibility, physicochemical, physico-mechanical, and environmentally friendly properties.

Numerous studies have reported the potential for increasing water retention properties after the use of synthetic polyacrylicacid [15] and polyacrylamide [16] hydrogel with a proven large capacity for water retention $[8,15]$. These acrylate-based products have been successfully used as soil conditioners to increase water holding capacity or nutrient retention of soils during practical agricultural testing [17-19].

Recently, various natural ingredients were effectively incorporated into hydrogels to increase their biocompatibility and biodegradability and resulted in novel hydrogels for agricultural applications-i.e., biodegradable cellulose-based superabsorbent $[3,20,21]$ hydrogels based on pectin, cashew gum, starch, Arabic gum [22], kernel gum [23], natural and semi-synthetic chitosan [12], various proteins, polysaccharides and their combinations with different cross-linking methods [6], and casein [24]. Nevertheless, the practical agricultural testing of their behavior under field conditions has been applied to few studies only. Practical use was presented e.g., by Demitri et al. [20] or Montesano et al. [3] who conducted pilot studies of the cellulose-based hydrogel with special attention to the changes in the water absorption capacity of the soil.

Acid whey is a dairy industry waste obtained from cheese production [25] for which the industry has long tried to find a sustainable utilization [26]. The increased demand for dairy products creates an excessive supply of acid whey (approximately $9 \mathrm{~kg}$ of whey per kilogram of cheese) that must be either disposed of or repurposed [27]. The worldwide production of whey is approx. $115 \mathrm{MM}$ tons annually which involves both sweet whey ( $\mathrm{pH}$ cca 6.0) with numerous utilizations in the food production and less beneficial acid whey ( $\mathrm{pH}$ cca 4.6) [28]. Applying the recent trends toward eliminating waste and keeping products in circulation, the various ways of acid whey valorization are investigated [29]. The whey is typically compound from proteins, lactose, milk fat, minerals, lactic acids, and amino acids [30]. The chemical properties of whey give it the potential to be used as a direct source of nutrients (N, P, K, S, Ca, Na, and Mg) [29,31,32], and as potential biological fertilizer for plant growth $[27,33]$.

For our experimental testing, acid whey was used as a base together with carboxymethylcellulose sodium salt and hydroxyethylcellulose cross-linked with citric acid to develop novel biodegradable hydrogel with the aim to obtain an effective soil conditioner with a high swelling capacity enabling optimal conditions to improve the soil quality in terms of water conservation and nutrients supply. In order to minimize the effects other than the dose and duration connected to the hydrogel application, the artificial soil was used as a standard soil medium and reference matrix [34]. Especially, the advantage is that the natural soil-inherent diversity can be reduced under strictly controlled experimental conditions of a simple artificial soil system. The artificial soil mixture was prepared with sandy textures since the sandy soils are highly permeable with poor water retention capacity and nutrient deficiency [35]; hence, suitable candidates to examine the efficacy of the hydrogel application. 
Since the laboratory characterization of the novel whey/cellulose hydrogel crosslinked by citric acid showed a decent capacity for water uptake together with desirable properties of thermal stability and viscoelasticity [36], the objective of this study was to explore the effects of different soil-hydrogel mixtures on several critical soil parameters under controlled experimental conditions. The investigated soil parameters were chosen to cover the basic desirable properties (water retention characteristics), synergic ameliorative effects (nutritional status of soil), and the potentially adverse effects (undue $\mathrm{pH}$ drop, excessive mobilization of soil macro-elements). The main aim of this research is to determine the suitability of whey-based hydrogel for application in agriculture with benefits for environment and waste management by testing soil quality improvement after hydrogel application. The purpose of presented research was to prove the synergic effect of whey-based hydrogel amendment on soil water-holding capacity and the availability of nutrients under controlled conditions of artificial soil.

\section{Materials and Methods}

\subsection{Hydrogel Preparation and Analysis}

Carboxymethylcellulose sodium (Sigma Aldrich No.C5013, St. Louis, MO, USA) salt and 2-hydroxyethylcellulose (Sigma Aldrich No. 434973) (3\%) at a weight ratio of 3:1 were dissolved in the acid whey (a by-product of the milk processing) to yield the solution for hydrogel preparation. The citric acid in anhydrous form (Lach-Ner, Neratovice, Czech Republic) was added at concentrations equal to $10 \%$ wt as a cross-linking agent. The hydrogel samples were prepared according to the procedure detailed by Durpekova et al. [36]. The hydrogel samples were analyzed by accredited methods (Table 1) in the Research Institute for Soil and Water Conservation.

\subsection{Artificial Soil Mixture}

Soil composition was fixed by using artificial soil mixtures that cover the typical sandy soils, which are assumed to preferentially benefit from the hydrogel supplementation. It reduces both the variability of initial soil physio-chemical properties and the effects of field management effects of field soils (e.g., possible post-harvest residue input to cropland, the uncertainties of former fertilizing). The artificial soil (standard soil) was prepared according to the standard guidelines of ISO 11268-1:2012 [37]. Artificial soil consists of $10 \%$ finely ground sphagnum peat, $20 \%$ kaolinite clay, and $70 \%$ quartz sand. Quartz sand of $0.05-0.2 \mathrm{~mm}$ grain size from Střeleč, kaolinite clay ( $30 \%$ kaolinite) from Sedlec and commercially available sphagnum peat were used. The individual components were mixed with an electric mixer, dried spontaneously, and incubated for one month before use.

\subsection{Hydrogel Application in a Pot Experiment}

A pot experiment was set up with four variants in three replicates: the pure artificial soil as a control soil, artificial soil mixed with three variants of the hydrogel supply (Figure 1. Plastic planting containers with a volume equal to $3.2 \mathrm{~L}$ were filled with $3.6 \mathrm{~kg}$ of artificial soil with a bulk density of $1.22 \mathrm{~g} \cdot \mathrm{cm}^{-3}$. The prepared hydrogel was weighed and mixed with artificial soil in a particular amount (Figure 1). The soil-hydrogel mixtures were homogenized in the entire volume and irrigated immediately. Pots were watered with $0.5 \mathrm{~L}$ of pure water three times a week for a period of four weeks. Soils were sampled $24 \mathrm{~h}, 7$ days, and over the next 3 weeks after the experimental setup and basic chemical properties were determined.

Soil samples for physical soil properties were prepared for saturation (part physical properties). Presented values resulted from six independent measurements for each variant-i.e., control experiment with pure artificial soil without hydrogel and variants with a dose escalation of whey-based hydrogel in three soil-hydrogel mixtures. 


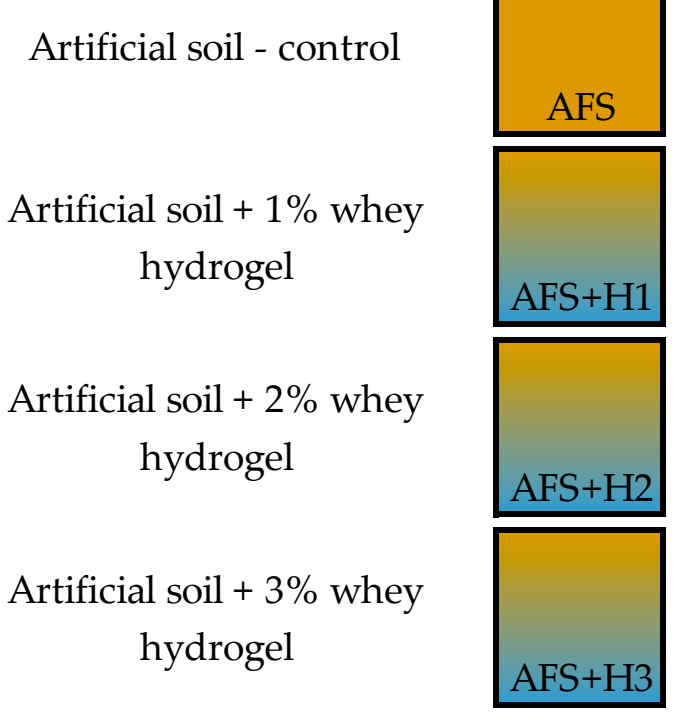

Figure 1. Pot experiment variants.

\subsection{Soil Analysis}

The purpose of the analyses was to evaluate the effect of the hydrogel amendment on the chemical properties of the soil. The analyses were performed in the accredited laboratory of the Research Institute for Soil and Water Conservation, Prague. The quality assurance of analytical data is guaranteed by the control process and certified methods of the analyses. For the soils from experiments, a stable set of chemical soil properties was determined, as given in Table 1.

\subsubsection{Chemical Properties}

Soil $\mathrm{pH}$ was determined by using the instrumental method [38] for the routine determination of $\mathrm{pH}$ using a glass electrode in a 1:5 (volume fraction) suspension of soil in water $\left(\mathrm{pH}_{\mathrm{H} 2 \mathrm{O}}\right)$; the content of organic carbon by sulfochromic oxidation according to ISO 14235 [39] and total nitrogen according to ISO 11261 [40] by the modified Kjeldahl method. The nutritional status of soil was explored using the available forms of the essential macronutrients ( $\mathrm{P}, \mathrm{K}, \mathrm{Ca}$, and $\mathrm{Mg}$ ) after the common extraction in the Mehlich III solution [41]. Mehlich III is a weak acid soil extraction used worldwide for extracting bioavailable nutrients in soils and is standardized as a combination of five reagents at a dilution ratio of $1: 10\left(0.2 \mathrm{~mol} \cdot \mathrm{L}^{-1}\right.$ glacial acetic acid, $0.25 \mathrm{~mol} \cdot \mathrm{L}^{-1}$ ammonium nitrate, $0.015 \mathrm{~mol} \cdot \mathrm{L}^{-1}$ ammonium fluoride, $0.013 \mathrm{~mol} \cdot \mathrm{L}^{-1}$ nitric acid, and $0.001 \mathrm{~mol} \cdot \mathrm{L}^{-1}$ ethylene diamine tetra acetic acid). The inductively coupled plasma optical emission spectrometry (ICP-OES) was used to analyze the extractions from the soil samples. As the complementary soil property for the potential of available nutrients, the cation exchange capacity (CEC) was measured by a barium chloride solution buffered at $\mathrm{pH}=8.1 \mathrm{using}$ triethanolamine [42].

Table 1. Overview of the studied chemical soil properties and used methods.

\begin{tabular}{cccc}
\hline & Method & Reference & Accuracy (\% rel.) \\
\hline $\mathrm{pH}$ & Determination of pH & ISO 10390 [38] & $4-5$ \\
$\mathrm{C}$ & Oxidimetric method & ISO 14235 [39] & $10-15$ \\
$\mathrm{~N}$ & Modified Kjeldahl method & ISO 11261 [40] & $15-20$ \\
$\mathrm{P}$ & Mehlich III solution & Mehlich (1984) [41] & 20 \\
$\mathrm{~K}$ & Mehlich III solution & Mehlich (1984) [41] & 20 \\
$\mathrm{Ca}$ & Mehlich III solution & Mehlich (1984) [41] & 20 \\
$\mathrm{Mg}$ & Mehlich III solution & Mehlich (1984) [41] & 20 \\
$\mathrm{CEC}$ & Barium chloride solution & ISO 13536 [42] & 20 \\
\hline
\end{tabular}




\subsubsection{Soil Physical Properties}

In this study, the maximum water capacity (MWC, full water capacity) and water holding capacity (WHC) were used as indicators for the effectiveness of hydrogel in improving water availability in soil. The soil hydraulic parameters were measured by the adjusted instrumental method according to EN 13041:2011 [43], ISO 11508:2017 [44], and ISO 11272:2017 [45]. The soil-hydrogel mixture was placed into a two-part volumetric stainless-steel ring. The prepared sample rings were placed into a water bath where the pure water gradually flowed in until it reached the height of $1 \mathrm{~cm}$ below the rims. The samples were then left to saturate for $24 \mathrm{~h}$. The saturated rings are weighed and then moved into sand tanks. The sand tanks are the PVC boxes with sealed bottom filled with multi-layered substrates and equipped with the suction cup with height compensator, allowing to create a partial vacuum where the negative fluid pressure is set as a function of the depression of the suction cup. The rings were left for suction for $48 \mathrm{~h}$ by the negative pressure of $1 \mathrm{kPa}$. After the first suction period, the two-part sample rings were separated-the upper part is removed and weighed, the lower part was given back into the sand tank and left for suction for the period of $48 \mathrm{~h}$ by the negative pressure of $3 \mathrm{kPa}$. After the second suction period, the sample rings were oven-dried at $105^{\circ} \mathrm{C}$ for the period until successive weighing agrees to $\pm 0.1 \mathrm{mg}$.

As soon as the sample rings were proceeded using the described instrumentation and the measured weights were gathered, the maximum water capacity (MWC) and water holding capacity (WHC) were calculated from the following equations:

$$
\begin{aligned}
& \mathrm{MWC}=(\mathrm{M} 1-\mathrm{M} 3) / \mathrm{V} 1 \times 100(\% \text { vol. }) \\
& \mathrm{WHC}=(\mathrm{M} 2-\mathrm{M} 3) / \mathrm{V} 1 \times 100(\% \text { vol. })
\end{aligned}
$$

where M1 is the mass of saturated sample including ring (g), M2 is the mass of the sample after the first suction section $(-1 \mathrm{kPa}, 48 \mathrm{~h}), \mathrm{M} 3$ is the mass of the sample with the ring after the second suction section $(-3 \mathrm{kPa}, 48 \mathrm{~h})$, and $\mathrm{V} 1$ is the measured volume of the steel ring. The first equation (Equation (1)) targets the soil state when practically all pore spaces are completely filled with fluid and there is plenty of water available to the crop at saturation. Only a portion of the available water is easily used by the crop, and hence, the second equation (Equation (2)) targets the available moisture that a given soil can hold for crop use. In the field conditions, soil texture and organic matter are the crucial determinants for soil water holding capacity, while in our artificial soil experiment these factors were fixed; hence, enabling us to observe the effects of hydrogel addition in various application rates.

\subsubsection{Statistical Analysis}

Soil samples were assayed in three (chemical properties) and six (physical properties) replicates for each analysis. The data were subjected to a normality analysis using the Shapiro-Wilk test. One-way ANOVA was conducted to test the significance of differences in the soil water characteristics among the different soil-hydrogel mixtures using the Statistica software (Version 10 for Windows; StatSoft, Inc., Tulsa, OK, USA). Statistical significance was considered at $p<0.05$ unless otherwise stated.

\section{Results}

The whey-based hydrogel was analytically characterized before the experiment. The chemical properties of hydrogel and artificial soil are given in Table 2. Measured $\mathrm{pH}_{\mathrm{H} 2 \mathrm{O}}$ was 4.17 . Since both the initial whey additive and cross-linking agent yielded a low $\mathrm{pH}$, the possible acidification may be a matter of attention due to several adverse effects of the $\mathrm{pH}$ drop on the availability of soil nutrients, and the toxicity or mobility of soil microelements. 
Table 2. Whey-based hydrogel characteristics.

\begin{tabular}{ccc}
\hline \multicolumn{3}{c}{ Hydrogel Characteristics } \\
\hline Properties & \\
\hline $\mathrm{pH}_{\mathrm{H} 2 \mathrm{O}}$ & \\
$\mathrm{C}$ & $\%$ & 4.17 \\
$\mathrm{~N}$ & $\%$ & 40.1 \\
$\mathrm{P}$ & $\mathrm{mg} \cdot \mathrm{kg}^{-1}$ & 1.26 \\
$\mathrm{~K}$ & $\mathrm{mg} \cdot \mathrm{kg}^{-1}$ & 6683 \\
$\mathrm{Ca}$ & $\mathrm{mg} \cdot \mathrm{kg}^{-1}$ & 13,059 \\
$\mathrm{Mg}$ & $\mathrm{mg} \cdot \mathrm{kg}^{-1}$ & 6093 \\
$\mathrm{CEC}$ & $\mathrm{mmol} \cdot 100 \mathrm{~g}^{-1}$ & 806 \\
\end{tabular}

Direct chemical extraction of nutrients in whey-based hydrogel showed a shift of chemical composition towards higher contents and availability of three elements $(\mathrm{K}>\mathrm{P} \sim \mathrm{Ca})$ and relative depletion of nitrogen.

The artificial soil is characterized as a sandy soil with a near-neutral $\mathrm{pH}\left(\mathrm{pH}_{\mathrm{H} 2 \mathrm{O}}\right.$ was 7.6). Since the quartz sand dominates the artificial soil composition, the soil can be characterized as poor in nutrients (N, P, K) (Table 3) with a low cation change capacity, typical for sand-textured soils. Nevertheless, the admixture of sphagnum peat resulted in an above-average $\mathrm{C}_{\mathrm{ox}}$ content and relatively higher content of $\mathrm{Mg}$ or $\mathrm{Ca}$.

Table 3. Artificial soil characteristic.

\begin{tabular}{ccc}
\hline \multicolumn{3}{c}{ Artificial Soil Characteristics } \\
\hline Soil Properties & & \\
\hline $\mathrm{pH}_{\mathrm{H} 2 \mathrm{O}}$ & $\%$ & 7.65 \\
$\mathrm{C}_{\mathrm{OX}}$ & $\%$ & 2.54 \\
$\mathrm{~N}$ & $\mathrm{mg} \cdot \mathrm{kg}^{-1}$ & 0.075 \\
$\mathrm{P}$ & $\mathrm{mg} \cdot \mathrm{kg}^{-1}$ & 18.0 \\
$\mathrm{~K}$ & $\mathrm{mg} \cdot \mathrm{kg}^{-1}$ & 73.5 \\
$\mathrm{Ca}$ & $\mathrm{mg} \cdot \mathrm{kg}^{-1}$ & 3204 \\
$\mathrm{Mg}$ & $\mathrm{mmol} \cdot 100 \mathrm{~g}^{-1}$ & 487 \\
$\mathrm{CEC}$ & & 9.35 \\
\hline
\end{tabular}

\subsection{Effect of Hydrogel on Chemical Soil Properties}

There was observed a trend of $\mathrm{pH}$ drop with the changing ratios of soil to hydrogel in mixtures. Soil pH decreased after hydrogel application from 7.65 to $7.56(\mathrm{H} 1)$ and $7.52(\mathrm{H} 3)$ in a period of $24 \mathrm{~h}$ (Table 4). The lowermost $\mathrm{pH}$ was detected after the application of the H3 dose.

Table 4. $\mathrm{pH}_{\mathrm{H} 2 \mathrm{O}}$ values.

\begin{tabular}{cccc}
\hline & $\mathrm{pH}_{\mathbf{H 2 O}}$ & & \\
\hline Variant & $\mathbf{2 4}$ & $\mathbf{7}$ & $\mathbf{3}$ \\
\hline AFS control & 7.65 & 7.75 & 7.62 \\
AFS+H1 & $7.56^{* *}$ & 7.73 & 7.57 \\
AFS+H2 & $7.67^{* *}$ & 7.62 & 7.62 \\
AFS+H3 & $7.52^{* *}$ & 7.57 & 7.51 \\
\hline
\end{tabular}

** mean values significantly different at $\alpha=0.05$ compared to control. AFS control—artificial soil, AFS+H1—artificial soil with $1 \%$ of hydrogel, AFS+H2 - artificial soil with $2 \%$ of hydrogel, AFS+H3 - artificial soil with $3 \%$ of hydrogel.

The maximum $\mathrm{pH}$ drop was $1.7 \%$. The addition of whey hydrogel did not cause the soil $\mathrm{pH}$ to drop to a point that would be injurious to plants. Within 7 days there was perceptible lower $\mathrm{pH}$ in all variants with the hydrogel application but without statistical significance in the linear model. After 4 weeks after the hydrogel application, differences 
between hydrogel variants and control soil decreased (Figure 2) and soil pH stabilized again due to the buffering capacity of higher Ca content in both artificial soil and wheyhydrogel. In the artificial soil, the addition of hydrogel in testing doses did not cause a long-term decrease of soil $\mathrm{pH}$ and did not decline more than $3 \%$.

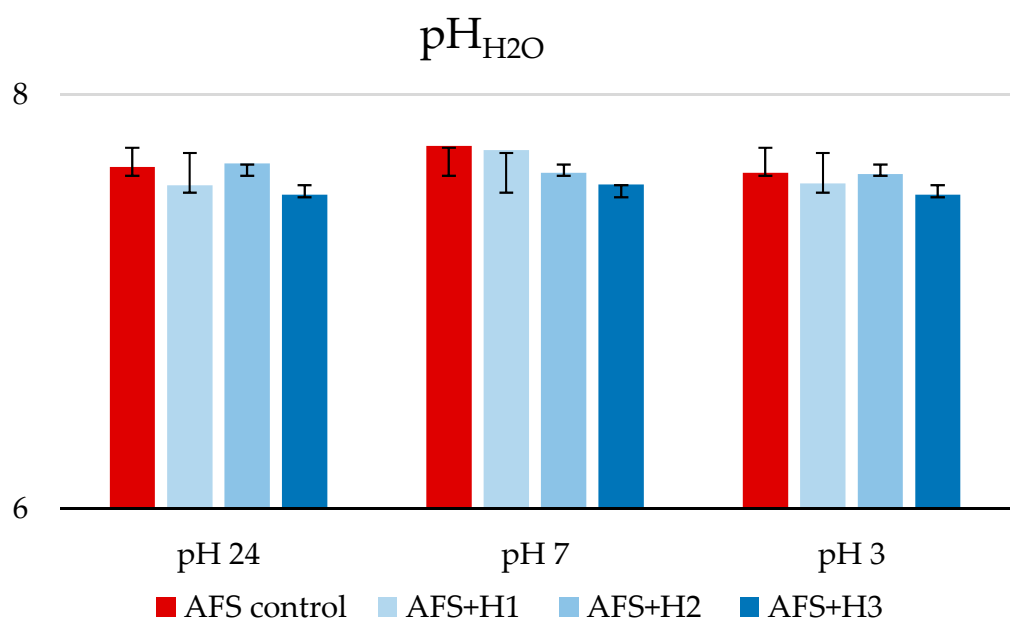

Figure 2. The effect of whey hydrogel application on soil $\mathrm{pH}_{\mathrm{H} 2 \mathrm{O}}$. AFS control-artificial soil, AFS $+\mathrm{H} 1$-artificial soil with $1 \%$ of hydrogel, AFS $+\mathrm{H} 2$-artificial soil with $2 \%$ of hydrogel, AFS $+\mathrm{H} 3-$ artificial soil with $3 \%$ of hydrogel, $\mathrm{pH} 24-\mathrm{pH}$ measured after $24 \mathrm{~h}, \mathrm{pH} 7-\mathrm{pH}$ measured after 7 days, $\mathrm{pH} 3-\mathrm{pH}$ measured after next 3 weeks.

The nitrogen content in the artificial soil (control) at the beginning of the experiment was $755 \mathrm{mg} \cdot \mathrm{kg}^{-1}$. As shown in Table 5, concentrations of this element immediately increased after the hydrogel addition while the highest content after the addition was found in the $\mathrm{H} 1$ variant. Differences between variants were very low and were not statistically significant. The nitrogen amount in whey hydrogel was very low and soil nitrogen was not affected by the hydrogel addition. After 7 days (Figure 3) from the hydrogel application, the amount of nitrogen further increased, and the highest amount of nitrogen contained variant with the highest amount of hydrogel. After another three weeks, a decreased content of nitrogen was found in all variants.

Table 5. Nitrogen, phosphorus, and potassium mean values in variants.

\begin{tabular}{ccccc}
\hline & Variant & $\mathbf{2 4}$ & $\mathbf{7}$ & $\mathbf{3}$ \\
\hline & AFS control & 755 & 800 & 700 \\
$\mathrm{~N}$ & AFS+H1 & 785 & 805 & 745 \\
& AFS+H2 & 780 & 885 & 670 \\
& AFS+H3 & 760 & 915 & 740 \\
\hline $\mathrm{P}$ & AFS control & 18 & 17 & 19 \\
& AFS+H1 & 21 & 24 & $27^{* *}$ \\
& AFS+H2 & $27^{* *}$ & $28^{* *}$ & $29^{* *}$ \\
\hline & AFS+H3 & $29^{* *}$ & $35^{* *}$ & 72 \\
$\mathrm{~K}$ & AFS control & 74 & 82 & 101 \\
& AFS+H1 & 102 & $99^{* *}$ & $113^{* *}$ \\
& AFS+H2 & $114^{* *}$ & $114^{* *}$ & $160^{* *}$
\end{tabular}

** mean values significantly different at $\alpha=0.05$ compared to control. AFS control—artificial soil, AFS+H1-artificial soil with $1 \%$ of hydrogel, AFS $+\mathrm{H} 2$-artificial soil with $2 \%$ of hydrogel, AFS $+\mathrm{H} 3$-artificial soil with $3 \%$ of hydrogel, 24-measured after 24 h, 7-measured after 7 days, pH3-measured after next 3 weeks. 

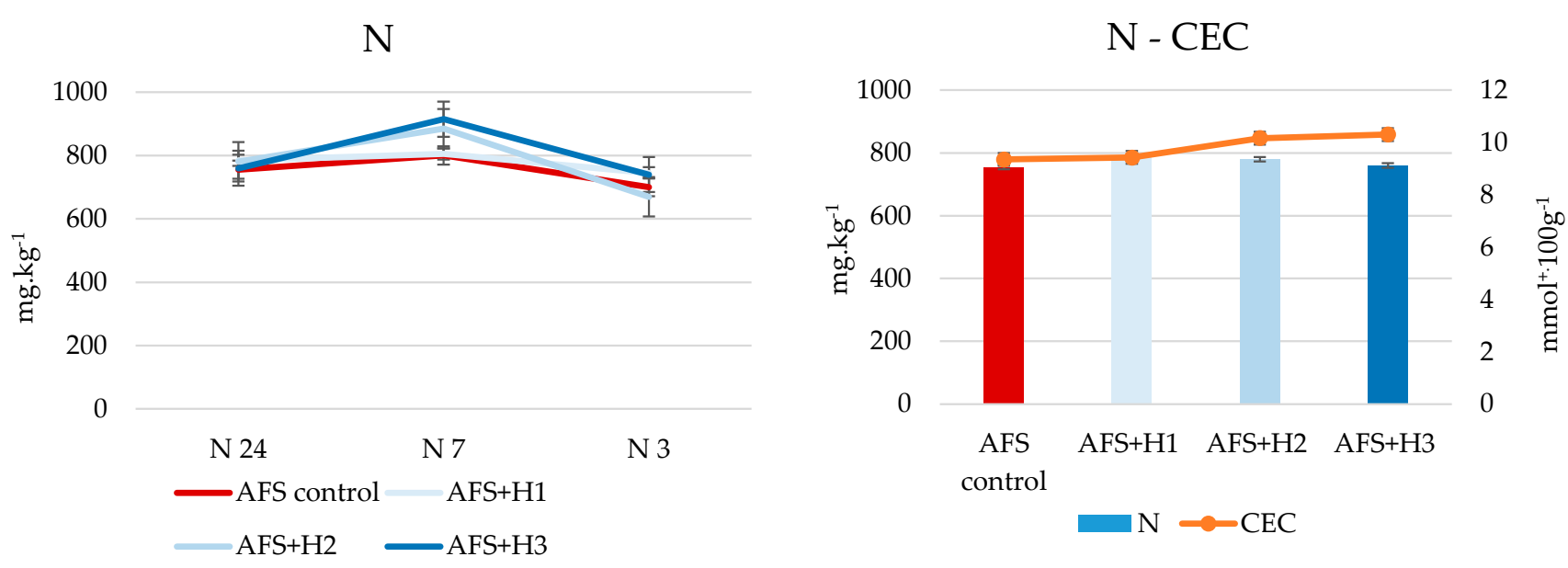

Figure 3. The effect of whey hydrogel application on nitrogen $(\mathrm{N})$ and cation exchange capacity (CEC). AFS controlartificial soil, AFS+H1-artificial soil with $1 \%$ of hydrogel, AFS $+\mathrm{H} 2$-artificial soil with $2 \%$ of hydrogel, AFS+H3-artificial soil with 3\% of hydrogel, N 24-N measured after 24 h, N 7-pH measured after 7 days, N 3-N measured after next 3 weeks.

The phosphorus content increased across all the hydrogel variants and sampling periods. After the hydrogel application, phosphorus increased immediately. The application of soil mixed with the highest hydrogel ratio (H3) increased phosphorus by about $50 \%$ compared to control, the same rise caused the mixture with the moderate ratio of hydrogel (H2). Lowest change (16\%) was following the application of the soil-hydrogel mixture H1 (Figure 4). Moreover, the available content of phosphorus increased also along the period of sampling after the application, and especially a boosting effect was the most radical for the mixture with the highest hydrogel proportion (H3). Nevertheless, major differences among soil-hydrogel variants were proved statistically significant (Table 5).

$\mathrm{P}$

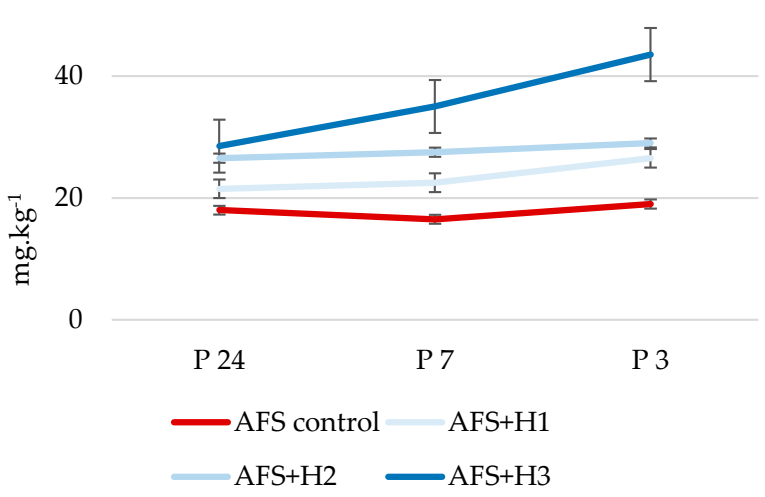

P - CEC

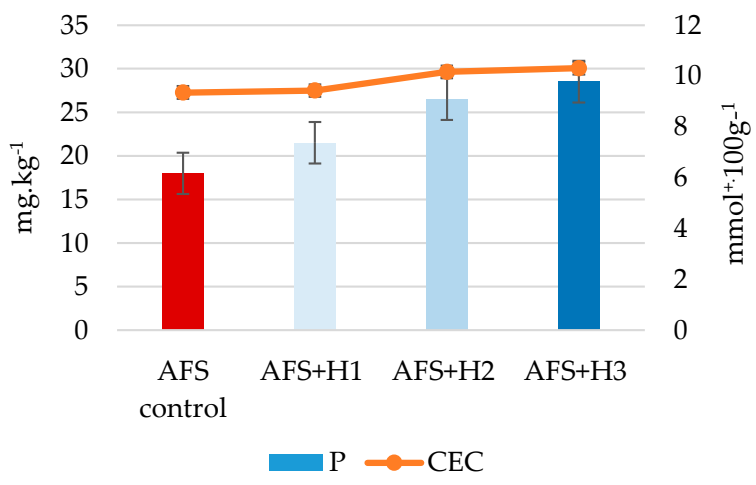

Figure 4. The effect of whey hydrogel application on phosphorus (P) content and cation exchange capacity (CEC). AFS control-artificial soil, AFS $+\mathrm{H} 1$-artificial soil with 1\% of hydrogel, AFS $+\mathrm{H} 2$-artificial soil with $2 \%$ of hydrogel, AFS+H3artificial soil with 3\% of hydrogel, P 24-P measured after 24 h, P 7-P measured after 7 days, P 3-P measured after next 3 weeks.

Potassium showed a similar trend of rapid increase similar to phosphorus after the hydrogel application. Application of whey hydrogel in the lowest soil-hydrogel proportion (H1) caused an increase by about 39\%, and with the increasing proportion of hydrogel to soil in the mixture, the relative enrichment of $\mathrm{K}$ increased up to $55 \%$ (the middle soilhydrogel proportion- $-\mathrm{H} 2$ ), resp. $84 \%$ (H3 variant). Similar to $\mathrm{P}$, the ameliorative effects of hydrogel application were temporally for K contents. In the contrary, the K contents remained stable for variants with lower proportions of hydrogel to soil (H1, H2 variants) 
(Figure 5). The K content significantly exceeded the control variant (up to $122 \%$ ) after the addition of the highest dose of hydrogel (H3). Significant differences in K contents among the soil-hydrogel variants were found using one-way ANOVA (Table 5).

K

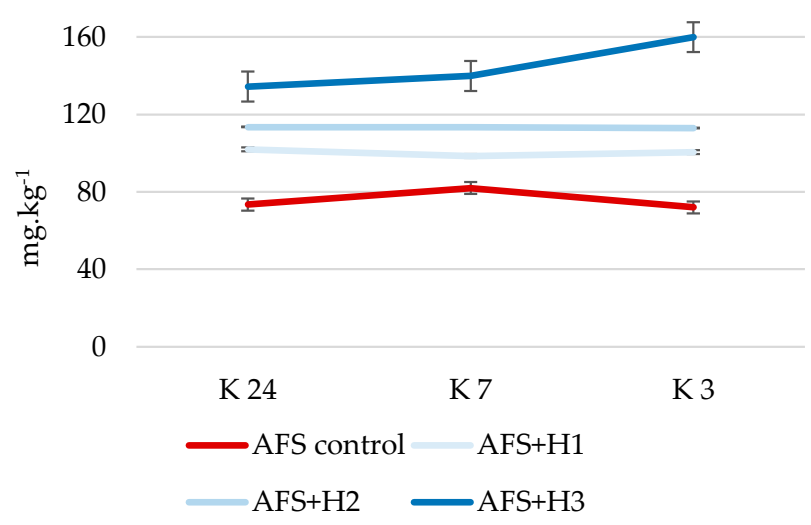

$\mathrm{K}$ - CEC

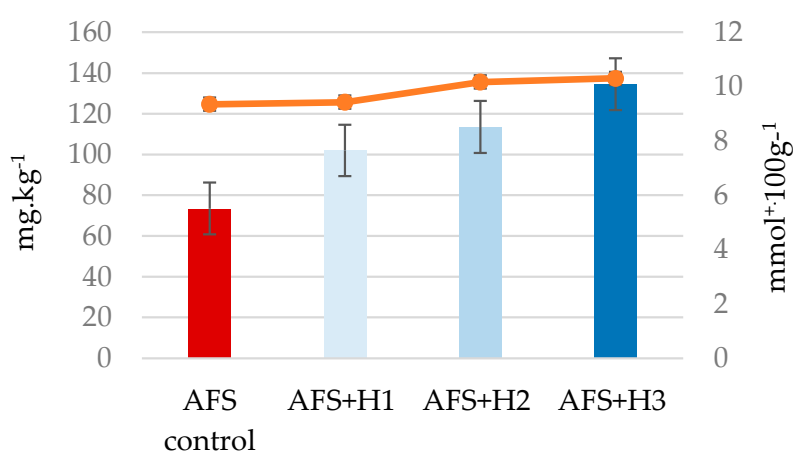

$\mathrm{K} \rightarrow \mathrm{CEC}$

Figure 5. The effect of whey hydrogel application on potassium content in soil and cation exchange capacity. AFS controlartificial soil, AFS+H1-artificial soil with $1 \%$ of hydrogel, AFS $+\mathrm{H} 2$-artificial soil with $2 \%$ of hydrogel, AFS+H3-artificial soil with $3 \%$ of hydrogel, K 24-K measured after 24 h, K 7-K measured after 7 days, K 3-K measured after next 3 weeks.

Generally, the results showed the gradual increase of nutrients' available pools with the changing hydrogel dose. As shown in Figures 3-5, along with the nutrients' level, cation exchange capacity (CEC) also significantly changed after hydrogel addition. Since the cation exchange capacity measured by a $\mathrm{pH} 8.1$ buffered barium chloride solution usually shows a decent correlation with exchangeable cations in soil samples, there was observed a similar dose gradient of CEC for various soil-hydrogel mixtures. Differences in soil CEC between control and hydrogel application were found evident soon after the application of the $\mathrm{H} 3$ dose into artificial soil and then remained relatively stable during the consecutive sampling periods.

The contents of available calcium and magnesium were also determined (Figure 6). In both cases, there was an immediate decline in the available nutrients' pools. After the application of hydrogel, the lowest values were determined after the application of the $\mathrm{H} 3$ dose in the first sampling period $(24 \mathrm{~h})$. The relative decrease of available Ca pools was proportional to the hydrogel dose in the mixture and decreased from $5.5 \%$ for the low dose (H1) up to 9 resp. 14\% for higher hydrogel doses (H2 resp. H3 dose). During the consecutive sampling periods, differences between soil-hydrogel variants and the control soil were still considerable while differences among particular soil-hydrogel variants were low. A similar trend was found in the case of magnesium, for which the hydrogel dose gradient in various soil-hydrogel mixtures resulted in an immediate decline by about 5 , 10 , and $16 \%$. These results confirmed the crucial role of soluble $\mathrm{Ca}, \mathrm{Mg}$ for buffering the hydrogel-induced acidification of soil. Since the experimental artificial soil was relatively rich in $\mathrm{Ca}$ and $\mathrm{Mg}$, the soil $\mathrm{pH}$ changes were controlled by their pools. The question about the soil acidification issues remains open for soils with very poor $\mathrm{pH}$ buffering capacity.

\subsection{Effect of Hydrogel on Physical Soil Properties}

In general, the determination of the physical properties of disturbed soils showed that the hydrogel additions increased the water retention properties in untreated soil (Figures 7 and 8); hence, the lowermost measured values for maximum water capacity (MWC, water field capacity, soil saturation) and water holding capacity (WHC) were mostly detected in control soils without the application of hydrogel. MWC values range from $44.94 \%$ (control) up to $46.75 \%(\mathrm{H} 2), 47.67(\mathrm{H} 2)$, and $49.95 \%(\mathrm{H} 3)$. In sandy artificial soil, the addition of $1 \%$ hydrogel (H1) increased maximum water capacity by $4 \%$, compared 
with untreated artificial soil (Figure 7). Amendment of $2 \%$ hydrogel (H2) had an increase of $6 \%$ compared to the control. Amending artificial soil by $3 \%$ of hydrogel (H3) led to an increase of maximum water capacity by about $11 \%$. Differences between single doses of hydrogel were not statistically proved and the highest influence on maximum water capacity was found after $\mathrm{H} 3$ dose application into artificial soil. Statistically proved was the difference between artificial soil (control variant without hydrogel application) and artificial soil with $3 \%$ of whey-hydrogel.

$\mathrm{Ca}$

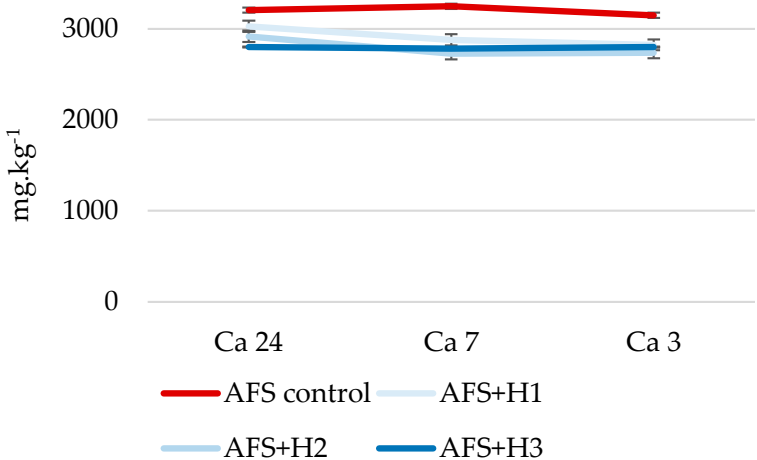

$\mathrm{Mg}$

1000

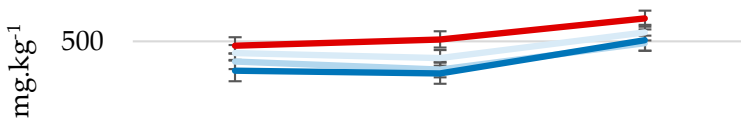

0

$\begin{array}{lll}\mathrm{Mg} 24 & \mathrm{Mg} 7 & \mathrm{Mg} 3 \\ \mathrm{AFS} \text { control } & \mathrm{AFS}+\mathrm{H} 1 & \\ \mathrm{AFS}+\mathrm{H} 2 & \mathrm{AFS}+\mathrm{H} 3 & \end{array}$

Figure 6. The effect of whey hydrogel application on calcium (Ca) and magnesium (Mg) content in soil. AFS control-artificial soil, AFS+H1artificial soil with $1 \%$ of hydrogel, AFS $+\mathrm{H} 2$-artificial soil with $2 \%$ of hydrogel, AFS+H3-artificial soil with $3 \%$ of hydrogel, Ca 24-Ca measured after $24 \mathrm{~h}$, Ca 7-Ca measured after 7 days, Ca 3-Ca measured after next 3 weeks, Mg 24-Mg measured after $24 \mathrm{~h}, \mathrm{Mg}$ 7-Mg measured after 7 days, $\mathrm{Mg}$ 3-Mg measured after next 3 weeks.

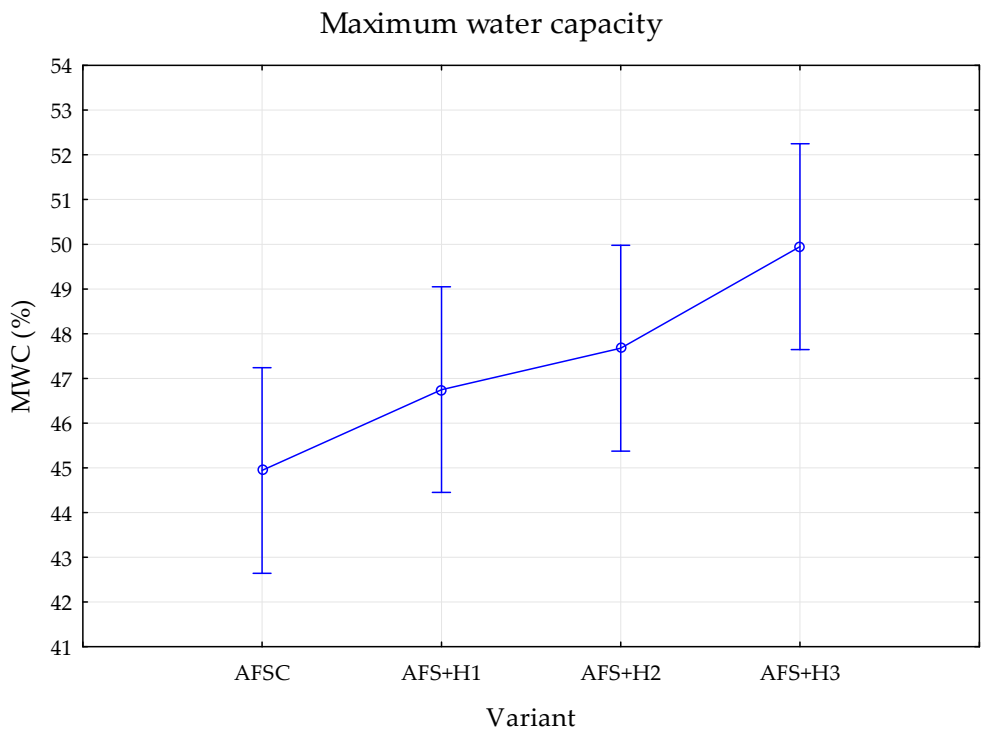

Figure 7. Maximum water capacity of single hydrogel variant, control and different doses of hydrogel, results of ANOVA. AFSC - artificial soil (control), AFS $+\mathrm{H} 1$-artificial soil with 1\% of hydrogel, AFS $+\mathrm{H} 2$ - artificial soil with $2 \%$ of hydrogel, AFS $+\mathrm{H} 3$ - artificial soil with $3 \%$ of hydrogel. 


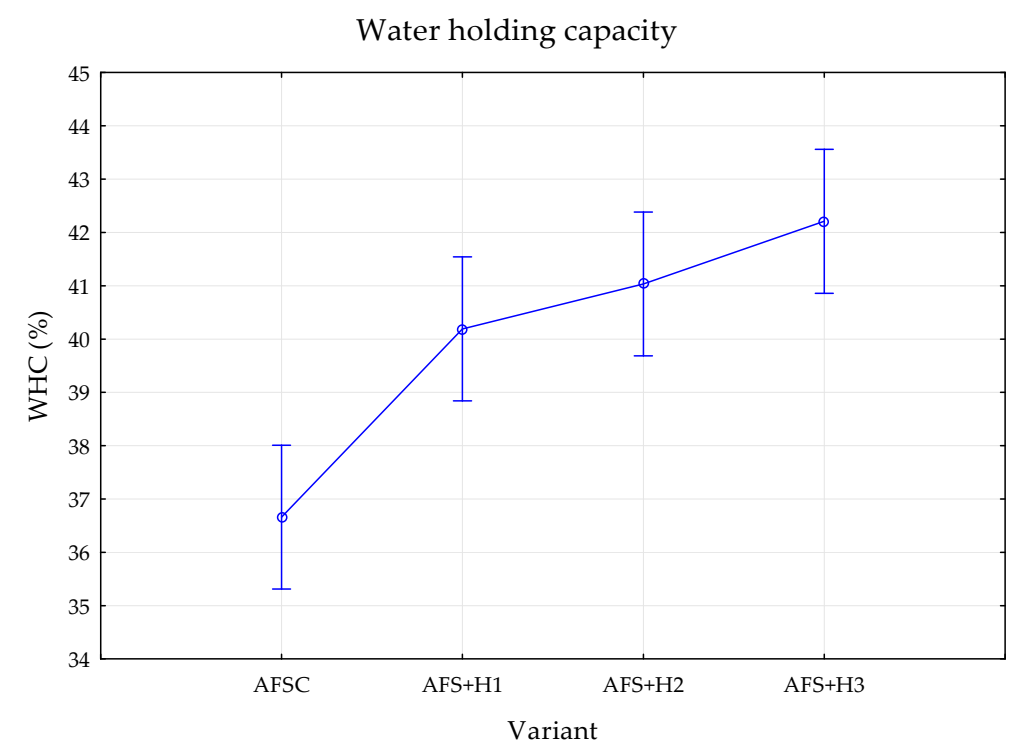

Figure 8. Water holding capacity of single hydrogel variant, control and different doses of hydrogel, results of ANOVA. AFSC - artificial soil (control), AFS $+\mathrm{H} 1$-artificial soil with $1 \%$ of hydrogel, AFS $+\mathrm{H} 2$-artificial soil with $2 \%$ of hydrogel, AFS $+\mathrm{H} 3$ - artificial soil with $3 \%$ of hydrogel.

Water holding capacity-available water-holding capacity is a key attribute, as it quantifies the amount of water available for plants. Water retention in the soil is strongly influenced by the soil composition, as well as the practices of soil use. The sandy artificial soil used for our experiment dispose of $36.66 \%$ WHC. As in the case of maximum water capacity, values of water holding capacity escalated from control variant up to variants amended with increasing doses of hydrogel (from $40.19 \%, 41.03 \%$, up to $42.21 \%$ ). Our results (Figure 8) showed an unequivocally positive effect of whey-based hydrogel on WHC. The addition of $1 \%$ of hydrogel into the artificial soil increased WHC by $10 \%$ compared to control soil. Under higher hydrogel doses (H1 resp. $\mathrm{H} 2$ dose), the water holding capacity was measured at the level of 112 resp. 115\% of the untreated variant. The mean WHC for various experimental variants were proved to significantly differ at the significance level $\alpha=0.05$. Statistically proved differences were between artificial soil (control variant) and all variants with hydrogel amendment and between variants with $1 \%$ of hydrogel and $3 \%$ of hydrogel.

\section{Discussion}

Synthetic hydrogels based on acrylates and acrylamides demonstrate high mechanical strength and the potential to absorb large amounts of water [46]. Due to the problem of their lower biodegradability, alternative (semi)natural biopolymers, such as alginate, agar, cellulose, chitosan, and starch, have been attempted to replace them [3,12,20-23]. In spite there are plenty of hydrogel formulations developed in laboratory conditions, only a few materials meet the requirements for effective and safe agricultural utilizations i.e., simultaneous nontoxicity and biodegradability with favorable properties for application (efficiency, applicability in field conditions) [47].

Several different polysaccharides have been used to prepare hydrogels as slow-release fertilizer hydrogels with both water retention and slow-release properties [22,48]. Although biopolymers could be used as macro- and micro-elements carriers for fertilization [46], our research aimed to test the straight use of whey-based hydrogel as nutrients' source for soil amelioration.

Often, the hydrogel in different forms (granular, particle) is mixed with soil at the $0.1 \%$ concentration ratio [21]. Miller and Naeth [9] tested the applicability of various doses-i.e., recommended dose (488 $\left.\mathrm{kg} \cdot \mathrm{ha}^{-1}\right)$, under- (one-half), and over-dosed (double) application of a synthetic acrylic hydrogel cross-linked with polyacrylamide for reclamation of mine- 
impacted soils. They concluded a high effect of applied co-substrates for creating hydrogelamended soil substrates for reclamation. Similar to our results, the effects of hydrogel addition led to initial high effects with application rate dependency on water retention that faded away with time from the application. Concerning the polyacrylate hydrogel, the common concentration ratios range between 0.1 and $0.4 \%[49,50]$. When combining chitosan with polyacrylamide hydrogel, Ritonga et al. [51] used the application rate of $0.1 \%$ for soil testing. During our study, the application rates were set to 1,2 , and $3 \%$ of whey-based hydrogel tally with amounts of cellulose-based hydrogels used for agricultural purposes [3,20]. Song et al. [52] applied 0.375, 0.650, and 0.975\% of lignosulfonate and sodium alginate hydrogel to optimize the soil available water content for tobacco crop grown in loess soils under drought experimental conditions.

Since the acid whey was the source material for the synthesis of hydrogel, and $\mathrm{pH}$ was recognized as one of the most important factors that control the healthy plant, the direct sequential measurements of $\mathrm{pH}$ changes were conducted after certain time intervals. Whey source as a mild acid suspension with typical solids concentrations near $8 \%$ has a high content of soluble salts (including $\mathrm{Ca}, \mathrm{Na}$, and $\mathrm{K}$ salts), and hence, its direct application into soil decreased soil $\mathrm{pH}$ and increases Ca solubility [53]. The mild acidity of whey usually resulted in soil $\mathrm{pH}$ drop by neutralizing soil solution (bi)carbonates and consequently, increased the solubility of calcium carbonates [54]. Long-term practicing of the land disposal of acid whey in the field conditions, the benefits of direct whey application were demonstrated for various soil-crop systems in Scotland [55], New Zealand [56], or the US [31,32,57]. The $\mathrm{pH}$ changes may temporally reach a range of $2 \mathrm{pH}$ units (depending on application rate, original soil $\mathrm{pH}$, and soil type) [58]. Especially for acid soils, the $\mathrm{pH}$ drop may temporally reach the point beyond the optimal range for crop production. On the contrary, the land-disposed whey rendered decent plant nutrition for crops on calcareous soils in the 7.6 to $8.8 \mathrm{pH}$ range under irrigation in an arid climate [54,59]. The $\mathrm{pH}$ drop may impact early plant development, and hence, it is recommended to postpone planting of sensitive crops to a few days later after whey application to eliminate soil acidity effect on germination. Analyzing the germination capacity of seeds and plant growth of three crops (soya, maize, broccoli), Grosu et al. [33] proved an inhibitory effect of whey over the germination process while the positive influence of whey addition on plants growth in the later development phase in a pot experiment. After the experimental synthesis of whey-based hydrogel, $\mathrm{pH}_{\mathrm{H} 2 \mathrm{O}}$ remained very low (4.17), i.e., with acidification risk. Similar to previous studies, $\mathrm{pH}$ swing was observed in our experiment-i.e., $\mathrm{pH}$ dropped immediately after the whey-based hydrogel application and steadied near the initial value in the consequent sampling periods. The $\mathrm{pH}$ change remained below one $\mathrm{pH}$ unit, probably because of a high Ca-content in the solution. Concerning the acidification issue, care should be taken to avoid potential mobilization of soil contamination in acid soils with enhanced contents of $\mathrm{pH}$ sensitive trace elements $(\mathrm{Cu}, \mathrm{Zn}, \mathrm{Ni})$. Trace element concentrations ( $\mathrm{Al}, \mathrm{Cu}, \mathrm{Zn}, \mathrm{Mn}$, and $\mathrm{Cr}$ ) are typically low in whey [31], and hence, the soil application should be proceeded with caution to trace elements in target soils. The temporal $\mathrm{pH}$ swing effect together with the ability to stimulate plant growth promotes open possibilities of using whey-based hydrogels as co-substrates for phytoremediation purposes. Also, the positive microbial biomass stimulation of whey makes it a candidate substrate for appropriate in situ bioremediation of different compounds [60]. The $\mathrm{pH}$ swing remains also very important because a significant effect of $\mathrm{pH}$ on the swelling ratio of natural-based hydrogels was observed under laboratory [36] and field conditions [20].

The nutritional benefits and feasibility of direct land disposal of whey were practically verified [32]. Land application of fresh acid whey does not present an odor issue, but it may turn problematic with time in storage and when co-stored with manure [58]. Considering that utilization of many soil conditioners is limited to seasonal application conditions, preparing stable whey-based hydrogel seems worth the effort. Especially when the nutritional benefits of whey are retained, as was shown in our experimental study with the artificial soil (Figures 3-6). Levels of nutrients in whey-based hydrogel during our experi- 
ment showed a shift of chemical composition towards higher contents and availability of three elements $(\mathrm{K}>\mathrm{P} \sim \mathrm{Ca})$. On the contrary, the results showed hydrogel relative depletion in nitrogen. However, more detailed research on the chemical composition of whey-based hydrogel from multiple sources of acid whey is required because the simultaneous ratios of macro elements play a crucial role when considering the synergic ameliorative effects of the application of whey-based hydrogels. The typical feature of whey's composition is an elevated proportion of $\mathrm{P}$ and $\mathrm{K}$. The initial composition of acid whey follows the technological process of milk processing-especially Ca variability in whey from the cheese production (Ca-bond with casein within cheese leading to depletion of $\mathrm{Ca}$ in whey) and curd cheese processing (in-soluble Ca-salts enriched the acid whey). Since the nutrient equilibrium is shifted towards $\mathrm{K}, \mathrm{Ca}$, and $\mathrm{P}$, the ameliorative effects rather trend to nutrition in K-deficit soils and targeting the situation where the optimal root growth is desirable. In soils with low sorption, K may be extensively pumped off from soils by plants, especially due to high demands of several crops. This process may be enhanced by the seasonal water deficit, and hence, the synergic effects of increasing water availability and K supplementation after hydrogel application may be worth considering. The direct positive nutritional effects were observed for various (semi)natural hydrogels [51] or there were observed the combined effects of hydrogel mixtures with different types of fertilizers based on the traditional NPK [61]. Konzen et al. [61] promoted a positive effect on the growth of Mimosa scabrella seedlings after application of combined hydrogel mixture, probably by retaining more water and enabling increased nutrient absorption. In our experiments, we tested both the ability to improve the soil water storing and fertilizing effects under various application rates of hydrogel. Similarly, the chitosan-coated three-layer compound fertilizer prepared from granular NPK coated with chitosan and poly(acrylic acid-co-acrylamide) superabsorbent polymer was used by $\mathrm{Wu}$ and Liu [62] and they proved well-controlled release effect and quantitatively described the slow-release mechanism of nutrients. Another multilayer-coated compound fertilizer prepared from NPK granules, polyvinyl alcohol, and chitosan was prepared by Noppakundilograt et al. [63] and they demonstrated increased release of nitrogen, phosphorus, and potassium nutrients. Our results showed similar trends as presented by Rittonga et al. [51] who observed significant changes in cation exchange capacity, levels of nitrogen, phosphorus, and potassium in the soil after introducing hydrogel synthetized by copolymerization of chitosan- $\mathrm{TiO}_{2}$ composite with polyacrylamide. Various application rates of hydrogel addition led to the differences in soil CEC among variants and in comparison to the control variant with the peak differences up to $38 \%$ for the hydrogel-rich mixture. Our results showed that the high application rate (H3 variant) increased immediately CEC by $10 \%$ and then remained stable for the duration of the experimental observation of the soil-hydrogel mixture. The differences among CEC values after three hydrogel application rates were not proved statistically significant at $\alpha=0.05$.

Concerning the potential of whey-based hydrogels to increase the efficiency of water use in soils, synthetic hydrogels proved to be more efficient even under lower doses necessary for water storage increase. Abdallah et al. [64] reported that an amendment of the sandy soil with $0.3 \%$ of fine-grained polyacrylamide hydrogel significantly increased the available water capacity. Agaba et al. [49] tested 0.2 , and $0.4 \% w / w$ polyacrylate hydrogel for its utilization for improving plant available water by an empirical estimation of the water content as the initial and terminal weights of pots in a tree survival study under experimentally induced drought conditions. They found that the addition of either 0.2 or $0.4 \%$ hydrogel to the five soil types, prolonged tree survival under water stress compared to the control variants. The higher hydrogel efficiency was observed for the sandy soils compared to loamy and clay soils. Johnson [65] denoted that the addition of super absorbent polymer hydrogel at the dose of $2 \mathrm{~g} \cdot \mathrm{kg}^{-1}$ improved the water holding capacity of sand from $171 \%$ up to $402 \%$. Similarly, Abedi-Koupai et al. [66] proved the effect of hydrogel treatment in the sequence clay < loamy soil < sandy loam soil. On the contrary, Akhter et al. [50] found no significant differences in the amount of plant-available 
water between loam and sandy loam soil treated with a polyacrylamide-acrylate hydrogel at three application rates $(0.1,0.2$, and $0.3 \%)$. The experimental results generally showed that well-drained soils (sandy loams, loams) are preferable for hydrogel treatment.

Compared to polyacrylic-based hydrogels, the natural-based hydrogels usually showed a lower yet significant effect on water retention in soil. Song et al. [52] showed that the addition of lignin/sodium alginate hydrogel can increase the maximum water holding capacity of soil with varying intensity from the initial $52.66 \%$ up to $55.64 \%, 58.69 \%$ resp. $61.63 \%$ following the hydrogel composition $(0.375 \%, 0.650 \%$, resp. $0.975 \%$ hydrogel $)$. The whey-based hydrogel used in our study increased maximum water holding capacity from the initial of $44.94 \%$ up to $46.75 \%, 47.67 \%$, and $49.95 \%$ following the application rate of hydrogel-1, 2 resp. 3\% hydrogel. Despite using different methods for establishing the effects of hydrogel on the soil water holding capacity, Montesano et al. [3] observed the water retention increase depending on the application rate of cellulose-based hydrogel $(0.5$, 1 , and $2 \%$ ). The same amounts of hydrogel from cellulose derivatives of pharmaceutical grade were used by Demitri (2013) [20]. The use of this hydrogel as water reservoir for the cultivation of vegetables was found to be extremely advantageous for release of water to the soil. The reason for divergences between various types of biodegradable hydrogel could be due to the differences in the macromolecular design of the different gels [49]. Nevertheless, the acrylic hydrogels are macromolecule composites with higher compression strength, which may determine their higher absorption characteristics in comparison to natural-based materials [67]. Since the novel whey-based hydrogel belongs to biodegradable composites with lower compression strength, the water-holding characteristics were measured relatively lower in comparison to the reported efficiency of synthetic hydrogels. According to the chemical compositions, whey-based hydrogels are expected to be higher biodegradable in comparison to synthetic super absorbents, but further investigations should be performed to assess the hydrogel degradation chemistry and kinetics in the soil under various conditions, as well as to evaluate the optimal hydrogel amount to be used for the cultivation of different plant species. Also, there is still a need for some technological solutions for the hydrogel delivery systems for broad field applications.

\section{Conclusions}

Sustainable agriculture strives to develop cropping systems where the soil sustains the plant productivity for population needs as well as preserves healthy status. Moreover, sustainable development generally turns the economy from linear to circular production, and hence, the efficient solution for eliminating waste and keeping products in circulation has also been developed in crop sciences. The crop vitality highly depends on both water availability and soil nutrition status. Our results showed the perspective of wheybased hydrogel for practical use in agriculture because the natural nutritional benefits of agricultural utilization of whey are enhanced by water retention abilities via the chemical cross-link of whey with citric acid. In the artificial soil experiment, the positive effects of $1 \%, 2 \%$, and $3 \%$ hydrogel addition on both water-holding properties and the temporal availability of nutrients were determined. The results show a clear influence of the whey hydrogel in increasing the water holding capacity with a maximum increase of $15 \%$. At the same time, no adverse side-effects for basic soil properties were observed after different levels of hydrogel had been introduced into the artificial soil. The application of $3 \%$ wheybased hydrogel during our experiment increased the available level of phosphorus and potassium up to 50 and $84 \%$, and the nutritional value of whey-based hydrogel with significant effects on elemental compositions may be beneficial during the critical phases in the early crop growth in both agriculture and forestry.

Author Contributions: Conceptualization, V.S., J.Č. and J.D.; methodology, J.Č., S.D. and A.Š.; formal analysis, J.Č.; data curation, J.S.; writing—original draft preparation, J.C.. and J.S.; writing-review and editing, J.S., R.V. and S.D.; visualization, J.Č.; supervision, V.S. and R.V.; project administration, J.Č, V.S. and J.D.; funding acquisition, V.S., J.D. and J.Č. All authors have read and agreed to the published version of the manuscript. 
Funding: This research was financially supported by the Ministry of Agriculture of the Czech Republic Project No. QK1910392 and Institutional support MZE-RO0218.

Institutional Review Board Statement: Not applicable.

Informed Consent Statement: Not applicable.

Data Availability Statement: Not applicable.

Conflicts of Interest: The authors declare no conflict of interest.

\section{References}

1. Schaller, N. The concept of agricultural sustainability. Agric. Ecosyst. Environ. 1993, 46, 89-97. [CrossRef]

2. Elshafie, H.S.; Camele, I. Applications of absorbent polymers for sustainable plant protection and crop Yield. Sustainability 2021, 13, 3253. [CrossRef]

3. Montesano, F.F.; Parentea, A.; Santamaria, A.; Sannino, A.; Serio, F. Biodegradable superabsorbent hydrogel increases water retention properties of growing media and plant growth. Agric. Agric. Sci. Procedia 2015, 4, 451-458.

4. Zhang, J.; Li, A.; Wang, A. Study on superabsorbent composite XVI. Synthesis, characterization and swelling behaviors of poly(sodium acrylate)/vermiculite superabsorbent composites. Eur. Polym. J. 2007, 43, 1691-1698. [CrossRef]

5. Chang, C.; Duan, B.; Cai, J.; Zhang, L. Superabsorbent hydrogels based on cellulose for smart swelling and controllable delivery. Eur. Polym. J. 2010, 46, 92-100. [CrossRef]

6. Klein, M.; Poverenov, E. Natural biopolymer-based hydrogels for use in food and agriculture. J. Sci. Food. Agric. 2010, 100, 2337-2347. [CrossRef] [PubMed]

7. Lin, C.C.; Metters, A.T. Hydrogels in controlled release formulations: Network design and mathematical modeling. Adv. Drug. Delivery Rev. 2006, 58, 1379-1408. [CrossRef]

8. Tomášková, I.; Svatoš, M.; Macků, J.; Vanická, H.; Resnerová, K.; Čepl, J.; Holuša, J.; Hosseini, S.M.; Dohrenbusch, A. Effect of different soil treatments with hydrogel on the performance of drought-sensitive and tolerant tree species in a semi-arid region. Forests 2020, 11, 211. [CrossRef]

9. Miller, V.S.; Naeth, M.A. Hydrogel and organic amendments to increase water retention in anthroposols for land reclamation. Appl. Environ. Soil Sci. 2019, 2019, 11. [CrossRef]

10. Sim, D.H.H.; Tan, I.A.W.; Lim, L.L.P.; Hameed, B.H. Encapsulated biochar-based sustained release fertilizer for precision agriculture: A review. J. Clean. Prod. 2021, 303, 127018. [CrossRef]

11. Ibrahim, M.; Abd-Eladl, M.; Abou-Baker, N.H. Lignocellulosic biomass for the preparation of cellulose-based hydrogel and its use for optimizing water resources in agriculture. J. Appl. Polym. Sci. 2015, 132, 42. [CrossRef]

12. Michalik, R.; Wandzik, I. A mini-review on chitosan-based hydrogels with potential for sustainable agricultural applications. Polymers 2020, 12, 2425. [CrossRef] [PubMed]

13. Wilske, B.; Bai, M.; Lindenstruth, B.; Bach, M.; Rezaie, Z.; Frede, H.G.; Breuer, L. Biodegradability of a polyacrylate superabsorbent in agricultural soil. Environ. Sci. Pollut. Res. 2014, 21, 9453-9460. [CrossRef] [PubMed]

14. Cannazza, G.; Cataldo, A.; De Benedetto, E.; Demitri, C.; Madaghiele, M.; Sannino, A. Experimental assessment of the use of a novel superabsorbent polymer (SAP) for the optimization of water consumption in agricultural irrigation process. Water 2014, 6 , 2056-2069. [CrossRef]

15. Chang, L.; Xu, L.; Liu, Y.; Qiu, D. Superabsorbent polymers used for agricultural water retention. Polym. Test. 2021, $94,107021$. [CrossRef]

16. Shahid, S.A.; Ansar, A.A.; Anwar, F.; Ullah, I.; Rashid, U. Improvement in the water retention characteristics of sandy loam soil using a newly synthesized poly(acrylamide-co-acrylic acid)/ $\mathrm{AlZnFe}_{2} \mathrm{O}_{4}$ superabsorbent hydrogel nanocomposite material. Molecules 2021, 17, 9397-9412. [CrossRef]

17. El-Rehim, H.A.; Hegazy, E.S.A.; El-Mohdy, H.A. Radiation synthesis of hydrogels to enhance sandy soils water retention and increaseplant performance. J. Appl. Polym. Sci. 2004, 93, 1360-1371. [CrossRef]

18. Kapłan, M.; Lenart, A.; Klimek, K.; Borowy, A.; Wrona, D.; Lipa, T. Assessment of the possibilities of using cross-linked polyacrylamide (Agro Hydrogel) and preparations with biostimulation in building the quality potential of newly planted apple trees. Agronomy 2021, 11, 125. [CrossRef]

19. Rudzinski, W.E.; Dave, A.M.; Vaishnav, U.H.; Kumbar, S.G.; Kulkarni, A.R.; Aminabhavi, T.M. Hydrogels as controlled release devices in agriculture. Des. Monomers Polym. 2002, 5, 39-65. [CrossRef]

20. Demitri, C.; Scalera, F.; Madaghiele, M.; Sannino, A.; Maffezzoli, A. Potential of cellulose-based superabsorbent hydrogels as water reservoir in agriculture. Int. J. Polym. Sci. 2013, 12, 1-6. [CrossRef]

21. Billah, S.M.R.; Mondal, M.I.H.; Somoal, S.H.; Pervez, M.N.; Haque, M.O. Enzyme-responsive hydrogels. In Cellulose-Based Superabsorbent Hydrogels; Mondal, M., Ed.; Cellulose Polymers and Polymeric Composites: A Reference Series; Springer: Berlin/Heidelberg, Germany, 2019; pp. 309-330.

22. Guilherme, M.R.; Aouada, F.A.; Fajardo, A.R.; Martins, A.F.; Paulino, A.T.; Davi, M.F.T.; Rubira, A.F.; Muniz, E.C. Superabsorbent hydrogels based on polysaccharides for application in agriculture as soil conditioner and nutrient carrier: A review. Eur. Polym. J. 2015, 72, 365-385. [CrossRef] 
23. Warkar, S.G.; Kumar, A. Synthesis and assessment of carboxymethyl tamarind kernel gum based novel superabsorbent hydrogels for agricultural applications. Polymer 2019, 182, 7.

24. Kruif, C.G.; Anema, S.G.; Zhu, C.; Havea, P. Water holding capacity and swelling of casein hydrogels. Food Hydrocoll. 2015, 44, 372-379. [CrossRef]

25. Mariotti, M.; Fratini, F.; Cerri, D.; Andreuccetti, V.; Giglio, R.; Angeletti, F.G.S.; Turchi, B. Use of fresh scotta whey as an additive for alfalfa silage. Agronomy 2020, 10, 365. [CrossRef]

26. Zotta, T.; Solieri, L.; Iacumin, L.; Picozzi, C.; Gullo, M. Valorization of cheese whey using microbial fermentations. Appl. Microbiol. Biotechnol. 2020, 104, 2749-2764. [CrossRef]

27. Akay, A.; Sert, D. The effects of whey application on the soil biological properties and plant growth. Eurasian Soil Sci. 2020, 9 , 349-355. [CrossRef]

28. Papademas, P.; Kotsaki, P. Technological utilization of whey towards sustainable exploitation. J. Adv. Dairy Res. $2021,7,231$.

29. Rocha-Mendoza, D.; Kosmerl, E.; Krentz, A.; Zhang, L.; Badiger, S.; Miyagusuku-Cruzado, G.; Mayta-Apaza, A.; Giusti, M.; Jimenez-Flores, R.; Garcia-Cano, I. Acid whey trends and health benefits. J. Dairy Sci. 2021, 104, 1262-1275. [CrossRef]

30. Zadona, E.; Blažić, M.; Jambrak, A.R. Whey utilization: Sustainable uses and environmental Approach. Food Technol. Biotechnol. 2021, 59, 147-161. [CrossRef]

31. Peterson, A.E.; Walker, W.G.; Watson, K.S. Effect of whey applications on chemical properties of soils and crops. J. Agric. Food. Chem. 1979, 27, 654-658. [CrossRef]

32. Watson, K.S.; Peterson, A.E.; Powell, R.D. Benefits of spreading whey on agricultural land. J. Water Pollut. Control Fed. 1977, 49, 24-34.

33. Grosu, L.; Fernandez, B.; Grigoras, C.G.; Patriciu, O.I.; Grig-Alexa, I.C.; Nicuta, D.; Ciobanu, D.; Gavrila, L.; Finaru, A.L. Valorization of whey from diary industry for agricultural use as fertilizer: Effects on plant germination and growth. Environ. Eng. Manag. J. 2012, 11, 2203-2210. [CrossRef]

34. Bielská, L.; Hovorková, I.; Kuta, J.; Machát, J.; Hofman, J. The variability of standard artificial soils: Cadmium and phenanthrene sorption measured by a batch equilibrium method. Ecotoxicol. Environ. Saf. 2017, 135, 17-23. [CrossRef] [PubMed]

35. Halecki, W.; Stachura, T. Evaluation of soil hydrophysical parameters along a semiurban small river: Soil ecosystem services for enhancing water retention in urban and suburban green areas. Catena 2021, 196, 104910. [CrossRef]

36. Durpekova, S.; Filatova, K.; Cisar, J.; Ronzova, A.; Kutalkova, E.; Sedlarik, V. A novel hydrogel based on renewable materials for agricultural application. Int. J. Polym. Sci. 2020, 2020, 13. [CrossRef]

37. International Organization for Standardization. Soil Quality-Effects of Pollutants on Earthworms-Part 1: Determination of Acute Toxicity to Eisenia Fetida/Eisenia Andrei. Available online: https://www.iso.org/standard/53527.html (accessed on 15 September 2021).

38. International Organization for Standardization. Soil Quality-Determination of pH. Available online: https://www.iso.org/ standard/40879.html (accessed on 15 September 2021).

39. International Organization for Standardization. Soil Quality-Determination of Organic Carbon by Sulfochromic Oxidation. Available online: https:/ / www.iso.org/standard/23140.html (accessed on 15 September 2021).

40. International Organization for Standardization. Soil Quality—Determination of Total Nitrogen-Modified Kjeldahl Method. Available online: https:/ / www.iso.org/standard/19239.html (accessed on 15 September 2021).

41. Mehlich, A. Mehlich 3 soil test extractant: A modification of Mehlich 2 extractant. Commun. Soil Sci. Plant Anal. 1984, 15, 1409-1416. [CrossRef]

42. International Organization for Standardization. Soil Quality-Determination of the Potential Cation Exchange Capacity and Exchangeable Cations Using Barium Chloride Solution Buffered at $\mathrm{pH}=8.1$. Available online: https://www.iso.org/standard/ 22180.html (accessed on 15 September 2021).

43. European Standard. Soil Improvers and Growing Media-Determination of Physical Properties—Dry Bulk Density, Air Volume, Water Volume, Shrinkage Value and Total Pore Space. Available online: https://standards.iteh.ai/catalog/standards/cen/b487 afb1-b8ce-4151-a8d8-fdb7959b2e3d/en-13041-2011 (accessed on 15 September 2021).

44. International Organization for Standardization. Soil Quality-Determination of Particle Density. Available online: https:// standards.iteh.ai/catalog/standards/cen/a540c124-0bd3-4c72-8152-b4d18b7c397c/en-iso-11508-2017 (accessed on 15 September 2021).

45. International Organization for Standardization. Soil Quality—Determination of Dry Bulk Density. Available online: https: //www.iso.org/standard/68255.html (accessed on 15 September 2021).

46. Skrzypczak, D.; Mikula, K.; Kossińska, N.; Widera, B.; Warchoł, J.; Moustakas, K.; Chojnacka, K.; Witek-Krowiak, A. Biodegradable hydrogel materials for water storage in agriculture-Review of recent research. Desalin. Water Treat. 2020, 194, 324-332. [CrossRef]

47. Pillai, C.K.S. Challenges for natural monomers and polymers: Novel design strategies and engineering to develop advanced polymers. Des. Monomers Polym. 2010, 13, 87-121. [CrossRef]

48. Ni, B.; Liu, M.; Lü, S.; Xie, L.; Wang, Y. Environmentally friendly slow-release nitrogen fertilizer. J. Agric. Food. Chem. 2011, 59, 10169-10175. [CrossRef]

49. Agaba, H.; Orikiriza, L.J.B.; Esegu, J.F.O.; Obua, J.; Kabasa, J.D.; Hüttermann, A. Effects of hydrogel amendment to different soils on plant available water and survival of trees under drought conditions. Clean Soil Air Water 2010, 38, 328-335. [CrossRef] 
50. Akhter, J.; Mahmood, M.; Malik, K.A.; Mardan, A.; Ahmad, M.; Iqbal, M.M. Effects of hydrogel amendment on water storage of sandy loam and loam soils and seedling growth of barley, wheat and chickpea. Plant Soil Environ. 2004, 50, 463-469. [CrossRef]

51. Ritonga, H.; Basri, M.I.; Rembon, F.S.; Ramadhan, L.O.A.N.; Nurdin, M. High performance of chitosan-co-polyacrylamide-TiO 2 crosslinked glutaraldehyde hydrogel as soil conditioner for soybean plant (Glycine max). Soil Sci. Ann. 2020, 71, 194-204. [CrossRef]

52. Song, B.; Liang, H.; Sun, R.; Peng, P.; Jiang, Y.; She, D. Hydrogel synthesis based on lignin/sodium alginate and application in agriculture. Int. J. Biol. Macromol. 2020, 144, 219-230. [CrossRef] [PubMed]

53. Graber, E.R.; Fine, P.; Levy, G.J. Soil stabilization in semiarid and arid land agriculture. J. Mater. Civ. Eng. 2006, 18, 190-205. [CrossRef]

54. Robbins, C.W.; Lehrsch, G.L. Cottage cheese whey effects on sodic soils. Arid Soil Res. Rehab. 1992, 6, 127-134. [CrossRef]

55. Berry, R.A. The production, composition and utilisation of whey. J. Agric. Sci. 1923, 13, 192-239. [CrossRef]

56. Radford, J.B.; Galpin, D.B.; Parkin, M.F. Utilization of whey as a fertilizer replacement for dairy pasture. N. Zealand J. Dairy Sci. 1986, 21, 65-72.

57. Sharratt, W.J.; Peterson, A.E.; Caibek, H.E. Effect of whey on soil and plant growth. Agron. J. 1962, 54, 359-361. [CrossRef]

58. Ketterings, Q.; Czymmek, K.; Gami, S.; Godwin, G.; Ganoe, K. Guidelines for Land Application of Acid Whey. Available online: http:/ /nmsp.cals.cornell.edu/publications / files / AcidWheyGuidelines2017.pdf (accessed on 3 August 2021).

59. Robbins, C.W.; Hansen, C.L.; Roginske, M.F.; Sorensen, D.L. Bicarbonate extractable K and Soluble Ca, Mg, Na, and K status of two calcareous soils treated with whey. J. Environ. Qual. 1996, 25, 791-795. [CrossRef]

60. Östberg, T.L.; Jonsson, A.P.; Bylund, D.; Lundström, U.S. The effects of carbon sources and micronutrients in fermented whey on the biodegradation of n-hexadecane in diesel fuel contaminated soil. Int. Biodeterior. Biodegrad. 2007, 60, 334-341. [CrossRef]

61. Konzen, E.R.; Navroski, M.C.; Friederichs, G.; Ferrari, L.H.; Pereira, M.D.O.; Felippe, D. The use of hydrogel combined with appropriate substrate and fertilizer improve quality and growth performance of Mimosa scabrella benth seedlings. Cerne 2017, 23, 473-482. [CrossRef]

62. $\mathrm{Wu}, \mathrm{L} . ; \mathrm{Liu}, \mathrm{M}$. Preparation and properties of chitosan-coated NPK compound fertilizer with controlled-release and waterretention. Carbohydr. Polym. 2008, 72, 240-247. [CrossRef]

63. Noppakundilograt, S.; Pheatcharat, N.; Kiatkamjornwong, S. Multilayer-coated NPK compound fertilizer hydrogel with controlled nutrient release and water absorbency. J. Appl. Polym. Sci. 2015, 132, 41249. [CrossRef]

64. Abdallah, A. The effect of hydrogel particle size on water retention properties and availability under water stress. Int. Soil Water Conserv. Res. 2019, 7, 275-285. [CrossRef]

65. Johnson, M.S. Effect of soluble salts on water absorption by gel-forming soil conditioners. J. Sci. Food Agric. 1984, 35, 1196-1200. [CrossRef]

66. Abedi-Koupai, J.; Sohrab, F.; Swarbrick, G. Evaluation of hydrogel application on soil water retention characteristics. J. Plant Nutr. 2008, 31, 317-331. [CrossRef]

67. Lentz, R.D. Polyacrylamide and biopolymer effects on flocculation, aggregate stability and water seepage in a silt loam. Geoderma 2015, 241, 289-294. [CrossRef] 